\title{
Analysis on the Logistics Cost Control of Self-Logistics System in the Electric Business Enterprise
}

\author{
Yu Gu, Shichao Gao \\ Beijing Wuzi University, Beijing, China \\ Email: Pie_star@163.com
}

How to cite this paper: Gu, Y. and Gao, S.C. (2016) Analysis on the Logistics Cost Control of Self-Logistics System in the Electric Business Enterprise. American Journal of Industrial and Business Management, 6, 1113-1121.

http://dx.doi.org/10.4236/ajibm.2016.612104

Received: October 24, 2016

Accepted: December 17, 2016

Published: December 20, 2016

Copyright $\odot 2016$ by authors and Scientific Research Publishing Inc. This work is licensed under the Creative Commons Attribution International License (CC BY 4.0).

http://creativecommons.org/licenses/by/4.0/

\begin{abstract}
In twenty-first century, the information revolution changes the way of human life, changes the enterprise business process, and further promotes the development of economic information and economic globalization. Especially in the new Internet era, the rapid development of E-business enterprise continues to heat up. Under the informatization of E-business enterprises, the circulation of commodities, logistics, capital flow and information flow unite highly. The important part of the development of E-business enterprises cannot be separated from the effective management and controlling of logistics costs, especially the cost of controlling of self-logistics system. The research on logistics cost management is very important for the E-business enterprise management. In order to survive and develop, the E-business enterprise according to the environment and their own development, must continuously improve the logistics cost management method, especially find a breakthrough point in the new economic environment, strengthen its logistics cost controlling, follow the trend of the times, and enhance the self-competitiveness. The article will discuss the logistics cost management status and existing problems in the self-logistics business enterprises, and put forward some suggestions.
\end{abstract}

\section{Keywords}

E-Business Enterprise, Logistics Cost, Management

\section{Introduction}

In the new economic environment, people's lifestyle has changed by widely used "Internet + ". Consumption and trading at home become easy and save time. At present, the electricity business enterprises keep pace with the times, not only developing the diversification and personalization of its business, but also thriving the business enter- 
prise's self-logistics services. The self-logistics services or third party logistics play a more and more important role in the national economy. People not only pay attention to the logistics value, but also put more emphasis on how to effectively reduce or control the logistics cost level in the modern logistics activities to maximize benefits under the new economic situation. With the deeper understanding of logistics, E-business enterprises realize the particular importance of research on logistics cost management.

Today, the appropriate reduction of logistics costs or to maintain the level of maximum economic efficiency is one of the important means of the E-business enterprises to achieve competitive advantage. It is also an important part to affect the E-business logistics management. The logistics activities show an increasing trend, and logistics costs are gradually increase, affecting the competitiveness of enterprises. According to the China Institute of Statistics database, in the three years the total cost of social logistics in China is nearly 10 trillion yuan per year, accounting for $18.0 \%$ of GDP, which is about twice as much as western developed countries or even more; the logistics costs were significantly higher. Logistics costs in developed countries account for an average of $10 \%$ to $15 \%$ of the final cost of finished products. However, in developing countries, logistics costs are significantly higher as a result of some inefficient factors. Especially, logistics costs in China are as high as $30 \%$ to $40 \%$ of production costs. In 2014 , more than 30 departments including the National Development and Reform Commission studied and prepared the Medium- and Long-term Development Plan for the Development of the Logistics Industry (2014-2020) and issued the Three-year Action Plan for Promoting the Development of the Logistics Industry (2014-2016). The logistics industry needs reform, transition and upgrading. According to data from the China Research Network, in the first seven months of 2015, the national social logistics cost reached 123.2 trillion yuan increased by 5.8 percent. The growth rate was 0.1 percentage point higher than that in the first half of the year. The total cost of social logistics was 5.8 trillion yuan with an increase of $4.2 \%$, but the growth rate declined slightly. At the national level, the Government supports the logistics enterprises transition and upgrading and integration of logistics resources by reducing logistics costs and improving logistics efficiency. In the new situation where reducing space of logistics cost is very large and logistics costs account for a high proportion, the research and management of E-business logistics cost are extremely important. Based on the influence of logistics information asymmetry on the logistics cost, the paper will discuss the existing problems of logistics cost calculation, lack of logistics and financial mixed talents, low logistics management level, and low logistics resources integration efficiency. And in view of the above problems, the paper will put forward some reasonable and effective suggestions to improve the quality and level of logistics cost management.

\section{Logistics Cost of E-Business Enterprise}

\subsection{The Concept of Logistics Cost of the E-Business Enterprise}

Logistics cost, an important part of the total cost of the E-business enterprise, is generally believed that the logistics is the space-time based displacement of objects or occu- 
pation of the time consumed by a variety of people's labor and currency forms of materializing labor. In the specific business activities, it includes packaging, handling, transportation, storage, distribution, processing and other aspects of the expenditure of human, material and financial resources. The logistics cost, according to different standards, has different classification. According to the different subject, logistics cost can be divided into self-logistics cost and third-party logistics cost. According to different logistics functions, it can be divided into transportation cost, storage cost, circulation processing cost, packaging cost, handling cost and logistics management information cost. According to different operation processes, it can be divided into forward logistics cost and reverse logistics cost.

\subsection{The Cost of Self-Logistics in E-Business Enterprises}

The purpose of E-business is providing users with comfortable experience and efficient service and realizing enterprise value, and the key is large-scale production and highly efficient operation of the process. As consumers increasingly demand logistics service efficiency, the larger and well-funded E-business enterprises began to build their own business logistics system providing higher quality logistics service in order to better satisfy customer requirements and improve competitiveness of enterprises. For example, Jingdong Mall is one of the representatives of self-built logistics system of E-business enterprises. The enterprise can save more logistics cost than third-party logistics cost. Its logistics is independent of other businesses, and it can fully control power of the logistics and maintain a strong competitiveness. Their internal staffs provide the logistics service, helping enterprise to manage and supervise. The enterprise uses real-time response system, barcode technology and EDI network technology, which reduce human error, improve efficiency and save money.

Self-logistics business enterprise's logistics costs can be divided into transportation cost, storage cost, circulation processing cost, management cost and so on. E-business enterprises build a huge logistics system, use advanced logistics technology and establish standardized and distribution logistics center, and this can effectively manage orders, transport and distribute. The enterprise is conducive to organize and supervise each logistics links with self-logistics system, in order to controlling and managing the logistics operations and logistics costs well. In addition, E-business enterprises with selflogistics system have their own warehouses, not only improving the speed and quality of delivery and user experience, but also reducing the middle part of enterprise logistics activities, which can give consumers a sense of caring and rest assured that is conducive to cultivating consumers loyalty.

\subsection{Logistics Costs of Other Logistics Model}

Because of lack of capital support, small E-business enterprises are more inclined to choose the third logistics service. The third party logistics service is a contract logistics, and it refers to the provision of professional logistics services for the supplier and the demander in the logistics channel, including all or part of the logistics service of the 
business enterprise. That model logistics costs can be converted into a basic agency costs and part of the cost of goods warehousing. This e-business enterprise controlling the logistics cost is far less than the self-logistics system cost, and it is not conducive to the supervision quality and efficiency of the third party logistics service, it may increase the return goods, order delaying, poor information transmission risk etc.

\section{The Current Situation Analysis of Cost Management of Self-Logistics E-Business Enterprise}

Now, the domestic logistics development is relatively mature, many enterprises pursue the "third profit source" theory proposed by the famous Professor Caesar Hsiu of Waseda University, the enterprises pay more and more attention to the management of the logistics cost [1]. In order to reduce the cost and strive for competitive advantage, the enterprises began to constantly refine the market, clear division of labor, to seek every link which can increase value, optimize management of the logistics cost and promote the overall development of the logistics. Now, there are still a lot of problems between the domestic logistics enterprises and the western countries. The following questions are worthy of our attention and analysis.

\subsection{Logistics Information Asymmetry}

Michael Potter in the "Information technology to bring the competitive advantage" (1985) and "Strategy and the Internet" (2001) demonstrated that information technology has a huge and far-reaching impact on industrial structure and the competitive advantage of enterprises. Information technology has increased density of the value chain of information, enriched the information content of the product, changed the industry structure and become important factors of competitive advantage in reducing costs, expanding differences and changing the competitive range [2]. Although information technology has a positive impact on the enterprise, the companies still have some problems to be solved.

The information asymmetry between enterprises:

First of all, the information asymmetry between the E-business enterprises results in that relevant logistics technology cannot be share and cannot share same nodes process so that logistics activities operate independent even with a network of logistics value chain. As a result, enterprise will repeat more logistics process, which not only increases the cost but also produces negative externalities to society. Second, the logistics information of enterprise cannot be timely delivered and decrease the overall efficiency of the logistics node operation. Third, the logistics department of enterprise is neglect of management or management concept, leading to the existence of precision error of logistics cost.

Inadequate information in the internal of E-business enterprises:

The second problem is the insufficient and involuntary disclosure of internal information of various departments of the enterprise. First of all, the management department cannot fully grasp the situation of enterprise operation so that the problems and 
defects of enterprises cannot be timely corrected. Second, the information feedback between the various departments of the enterprise arriving at the information center cannot be respond timely. For example, because of ineffective communication between production department and sales department, it will lead to the purchasing department's purchasing plan cannot be accurately adjusted so that the products cannot meet the market demand, causing the excessive waste and useless waste. Insufficient use of information making the enterprise in a passive position, it is unable to get the initiative in the fierce competition.

The untimely information between enterprises and consumers

Enterprise suppliers and consumers are relatively independent of the individual, and they all pursue to maximize value and greater economic benefits. Therefore, there is not only existence of untransparent information, but also the existence of delay between them. Because that consumer demand information cannot be timely delivery to the E-business enterprise information center or demand information delivering to the business enterprise timely is not timely deal with, it will still cause delay and demand information and supply information does not match, such as product information, purchase information, transportation, after-sales service, etc. Delay, availability, transparency of the information can impact on operation efficiency directly.

\subsection{Difficulty of Accurate Calculation of Logistics Cost}

In recent years, China's E-business development is more mature, and the logistics service also has a considerable development, but the level of logistics management should to be improved. One problem is lack of a unified management of business enterprise logistics. Because of more logistics operations parts and more elements distribution of the various departments, the enterprise cannot grasp and control the logistics cost, and it increases the hidden logistics cost and the difficulty of logistics cost accountant calculation [3]. Second, the logistics cost accounting scope is very extensive and be related to the whole process of logistics. Now enterprise is lack of specific accounting standards and unified approach of the logistics calculation scope. Due to its own characteristics of the logistics costs, it is difficult to fully solve the problem and the enterprise is still unable to accurately grasp the logistics costs.

\subsection{Lack of Logistics and Financial Mixed Talents}

Because of the wide range and the complexity of logistics cost, and financial accountant who is lack of logistics expertise, it leads to the existence of the logistics cost accounting errors. Although China's continuous improvement of accounting standards and regulations, financial accountant and management accountant improve their experience of financial management, these people who without formal education related knowledge of logistics and logistics cost, the financial people are lack of the concept of logistics cost accounting and controlling. Therefore, logistics financial mixed talents need to be cultivated, which is also an effective strategy of actuarial logistics cost. 


\subsection{Low Logistics Management Level}

First of all, the business enterprises are lack of modern logistics management concepts and awareness. It is difficult to develop a unified logistics management system, and management level has been reduced due to lacking of standardization of logistics operation process. Second, the E-business enterprise logistics management mode is falling behind, and is mainly behaved in the irrational and unscientific system structure, decentralized management of logistics department, and ignoring the integration of the supply chain. So that it makes enterprise logistics operation has too many intermediate links and serious waste. Third, some enterprises are often concerned about the cost of warehousing and transportation costs in the logistics cost management, while ignoring the cost of inventory and logistics management costs, and increase the difficulty of management.

\subsection{Low Logistics Resources Integration Efficiency}

The vigorous development of the E-business enterprise drives the development of the logistics of our country, and the existing logistics resources in China is very rich and the logistics infrastructure is relatively improved, such as large-scale logistics warehouse, Port Economic Zone, etc. In addition, China's transport capacity has reached a high level, and transport and logistics facilities develop rapidly. At present, logistics enterprise has been widely used in modern transport tools, such as a laser guided vehicle, three-dimensional warehouse, automatic loading and unloading mechanical equipment etc. Although China's logistics industry already has the basic conditions, the biggest problem is the resource integration: how to effectively allocate the existing logistics resources, how to make the resources to form high efficiency supply chain system in the integration process, and then how to form a complete logistics system to enhance the competitiveness of logistics enterprises [4]. Therefore, the integration of logistics resources is one of the most urgent problems of E-business enterprise to solve.

\section{Some Suggestions on the Cost Management of the Self-Logistics E-Business Enterprise}

\subsection{Establish Information Sharing Platform and Improve Information Transparency}

With information technology development, the advantage of the E-business enterprise to improve the efficiency is the degree of grasping information and the ability of dealing with information. The E-business enterprises establish information sharing platform including enterprise external information sharing platform and enterprise internal information sharing platform. External information sharing platform provides product information, service information, and logistics information for the business enterprise, and enterprises can cooperate with each other to achieve a win-win situation and making the resource optimization. The enterprise internal information sharing platform is used for publishing the business information of the production department, purchasing department, logistics department and customer service department, and it 
forms a truly dynamic network in the circulation of product that before product, being produced, on sales and after sale. The network helps various departments to supervise mutually and cooperate, so as to reach a maximum efficiency and reduce the logistics cost relatively. Of course, the establishment of norms in the process of information collection, transmission, storage, sharing and decision-making not only depends on the information system, also need legal support to make ensure safe and accurate of the information.

The establishment of information sharing platform creates friendly environment for logistics informatization, improves the application level of logistics informatization, and integrates enterprise logistics resources effectively. It is important role is response to consumer demand, timely delivery of logistics, in order to improve the efficiency of resource allocation and overall efficiency of business enterprise.

\subsection{Effectively Use of Activity-Based Costing Method Accounting Logistics Cost}

E-business enterprise informatization is bound to establish storage management systems, transportation management systems, customer relationship management systems and financial management systems, and financial management system is an important part of the cost analysis system. Nowadays, in the research of logistics cost, the quota method and activity-based costing method are mainly used in our country. Activitybased costing method is based on links of the logistics operations, including packaging, warehousing, transportation, loading and unloading and other aspects of a clear division of labor that managed and controlled the costs by using financial management system [5]. Financial accountants use the financial management system accounting the logistics cost, including all aspects of orders, procurement, transportation, storage, distribution and other transactions. And it statistics, supervises and accounts the cost data by using the latest technology, to make the logistics cost accounting more accurate. On the basis of information, the enterprises can make full use of activity-based costing method, so as to effectively control and manage the cost.

\subsection{Improve the Management Level and Reduce the Hidden Cost of Logistics}

First, the enterprises should improve logistics management awareness and management level. The managers should be trained to enhance their professional literacy. Second, based on the design of the comprehensive plan of the enterprise logistics, the enterprises will form a complete logistics system which can share the resources of different departments and reduce the invalid operation of goods storage, transportation, and distribution. It can coordinate development of various functions and elements of logistics system in unity. Third, the enterprises make full use of the information sharing platform to improve the overall efficiency of enterprises.

\subsection{Improve the Quality of Products and Service Levels}

The informatization makes all kinds of transaction information, consumers can fully 
inform every link by channels and product information exchanging in the network, and reduce the cost of returns. The enterprises should improve product quality and service level. At the same time, the enterprise can release the production information to the external information sharing platform, so that consumers can inform the real information of the products, improving the reliability of the products and reducing the level of return. Secondly, the enterprise should effectively use customer relationship management system and timely response to all consumer demand, improving consumer acceptance of the enterprise. Third, enterprises should establish the concept of customerfirst-service, cultivate high-quality service, and then improve consumer satisfaction, which is conducive to reducing the return rate, saving logistics costs.

\subsection{Improve Integrity and Establish the Enterprise Credit System}

How to make consumers identify information effectively of their own enterprises is a question. The enterprises need to increase the discernibility, authenticity and security of the information. The key factor is the integrity of enterprises [6]. Integrity is an important part of corporate culture, and is the basis for long-term development of enterprises. Improving enterprise integrity can increase trust and loyalty of consumers, and the loyalty can expand the market and establish the brand. Integrity requires social supervision and legal support. Today, Chinese government attaches great importance to the business enterprise and the integrity. The general office of the State Council issued document No. 2 (2005) "Several opinions on accelerating the development of E-commerce". The document presents several opinions on the development of our E-business enterprise planning, development strategy and requirements, and a lot of content of the document requires enterprises to establish credit system, business enterprise environmental integrity, and integrity evaluation and service mechanism, so as to promote the healthy development of China's E-business enterprise. This shows that it is essential for the E-business enterprise establish a credit system.

\section{Conclusions}

E-business enterprise's logistics cost management becomes more and more necessary and important, and the reduction of logistics cost to a reasonable level is the result of multi factors. At the macroscopic level, "The long-term planning of logistics industry development (2014-2020)" issued by the State Council pointed out: country needs to increase land and other policy support, and spare efforts to reduce logistics costs. These support policies are more conducive to the E-business enterprise with large scale selflogistics and long-term development. In addition, the government should support the development of the logistics industry and establish relevant legal system which regulates the behavior of the industry. That provides a good operating environment and legal environment for the business enterprise and other enterprises. At the microscopic level, self-logistics E-business enterprise should make an overall planning of enterprise development and a long-term goal. Improving logistics system makes enterprises achieve their own self optimization, transition and upgrading, and promotes the good develop- 
ment of business and logistics services.

At present, logistics cost management level of self-logistics E-business enterprises is poor, and improvement and refinement of the system is necessary. So enterprises face the development opportunities and challenges. How to reduce logistics costs and achieve competitive advantage in the new Internet environment is a big problem that every enterprise must answer and solve in the further development of the trend of economic globalization. The self-logistics E-business enterprise has many problems of the logistics cost management, and they should effectively control and manage the cost according to their own advantage, improve logistics management level, improve the quality of products and service level and establish credit mechanism to improve the integrity of the enterprise. Only in these ways, E-business enterprises can effectively reduce the logistics cost, promote competitiveness, and occupy a space for themselves in the fierce competitive market.

\section{References}

[1] Song, H. and Wang, L. (2009) The Status and Development of Logistics Cost Management of Chinese Enterprises. Journal of Renmin University of China, No. 4, 89-96.

[2] Poter, M.E. (2005) Competitive Strategy. Huaxia Publishing House, Beijing.

[3] Huang, X.M., Liu, D.C. and Zhou, Y.F. (2006) The Corresponding Study Abroad, the Frontier and Progress of Research on Logistics Cost of Commercial. Commercial Research, No. 23, 203-209.

[4] Wang, X. and Wang, Z.Y. (2009) The Realization Path of Logistics Informatization under the Environment of E-Commerce. Business Era, No. 34, 21-22.

[5] Zhao, Y. and Wang, J. (2013) Study on the Cost Control Strategy of Small and Medium Sized Logistics Enterprises in the Perspective of Information Technology. Logistics Technology, No. 2, 45-46.

[6] Li, J. (2015) Business Enterprise Logistics Cost Control and Research. Shopping Mall Modernization, No. 12, 69.

\section{Submit or recommend next manuscript to SCIRP and we will provide best service} for you:

Accepting pre-submission inquiries through Email, Facebook, LinkedIn, Twitter, etc. A wide selection of journals (inclusive of 9 subjects, more than 200 journals)

Providing 24-hour high-quality service

User-friendly online submission system

Fair and swift peer-review system

Efficient typesetting and proofreading procedure

Display of the result of downloads and visits, as well as the number of cited articles

Maximum dissemination of your research work

Submit your manuscript at: http://papersubmission.scirp.org/

Or contact ajibm@scirp.org 